\title{
What is the Contribution of the Theory of Redistribution Systems to the Theory of Corruption? ${ }^{1}$
}

\section{Tomáš Otáhal, ${ }^{2}$ Milan Palát, ${ }^{3}$ Petr Wawrosz ${ }^{4}$}

\begin{abstract}
Scholars making economic policy recommendations to resolve corruption problem use several approaches, the most dominant of which are the principal-agent and rent-seeking theories. In this paper, we argue that the principal-agent theory has problems to account for the environment in which the agents offering and accepting corruption operate, and explain the importance of agents for survival of their environment. The rent-seeking theory, on the other hand, finds it difficult to establish socially effective legislation and ways to determine the barriers to entry that motivate agents to behave corruptly. Both problems, however, are vital for solving the problem of corruption. Lacking the knowledge of the agent's environment (system) and their significance for survival of the system, the theory cannot define incentives that would discourage the agent from acting in a corrupted way. If the rent-seeking theory does not determine the barriers to entry that motivate agents to behave corruptly, it cannot determine the proper legislation that would deter corrupt behaviour and lead to economic development. For these reasons we investigate if both problems can be explained and solved within the alternative theory of redistribution systems and its part - the theory of parallel redistribution games.
\end{abstract}

Key words: Corruption, redistribution system, parallel redistribution game, game theory

JEL Classification: D72, D74, D82, C71

\footnotetext{
${ }^{1}$ This article is a result of the research project supported by the Ministry of Education, Youth and Sports of the Czech Republic, no. VZ 6214648904 The Czech Economy in the Process of Integration and Globalization, and the Development of the Agricultural Sector and the Sector of Services under the New Conditions of the Integrated European Market", thematic area 01 "Macroeconomic and microeconomic performance of the Czech economy, and the Czech government's economic-political measures in the context of the integrated European market". An earlier draft of the paper was presented at Modern and Current Trends in the Public Sector Research Conference held in Sllapanice (Faculty of Economics and Administration, Masaryk University) in 2012. We would like to thank Ing. Marek Pavlík, Ph.D., from the Faculty of Economics and Administration of Masaryk University, and other participants for valuable comments on this project. Special thanks must be expressed to two anonymous reviewers of our article for their remarks who helped us more precisely explain our ideas and give us direction for the further research.

${ }^{2}$ Department of Economics, FBE MENDELU in Brno, Zemědělská 1, 61300 Brno, Czech Republic, e-mail: tomas.otahal@mendelu.cz.

${ }^{3}$ Department of Territorial Studies, Faculty of Regional Development and International Studies, Mendel University in Brno, Zemědělská 1, 61300 Brno, Czech Republic, e-mail: mpalat@mendelu.cz.

${ }^{4}$ The University of Finance and Administration, Faculty of Economic Studies, Estonská 500, 101 00 Prague 10, e-mail: wawrosz@ mail.vsfs.cz.
} 


\section{Introduction}

Corruption is considered to be one of the most serious dangers which threaten any democratic society (Bardhan 1997, Lambsdorff 2002, Lambsdorff 2007). Therefore, many forms of corruption are regarded as criminal acts and they are penalized by the police and other relevant state authorities. Nevertheless, in order to be able to fight corruption effectively, a democratic society needs not only practical methods for this fight, but also an effective theory which defines the forms of corruption, how these forms threaten the society, which methods of fighting are effective and which are not.

Corruption is one of the forms of human action (Mieses 1949, Otáhal 2006). Economics as a science about human action belongs necessarily among the disciplines which should address corruption on a scientific level. In this discipline it is pointed out that corruption is a voluntary action of both the person who is being bribed and the person who is the provider of the bribe, and it brings some benefit to both sides (Treisman 2000, Lambsdorff 2007, Colombatto 2003, Otáhal 2007b). From this standpoint there is nothing wrong about corruption. But the resources used for the corruption should not be used for anything else. Corruption harms a third party which does not participate in the corruption contract - the economic theory (Lambsdorff 2007) points out that corruption brings no benefit to the third party. The standard economic theories explaining corruption are: 1) Principal-agent theory, 2) Rent-seeking theory. We think that neither of these explains the issue of corruption sufficiently. In our opinion, they both are narrow-minded and there is a need of a more general theory. The article explains why, in our view, the principal-agent and the rent-seeking theories fail. Our explanation shows that the theory which is aimed at defining corruption effectively and at evaluating methods of the fight against it has to: 1) describe the corruption environment, and 2) define the importance of the corrupted person and of the bribed one for the survival and development of the corrupted system. An effective theory which seems to be able to do so is the theory of redistribution systems (Valenčík and Budínský 2009) and a parallel game theory (Valenčík 2008). First, the article deals with the general definition of corruption including why corruption represents a problem. The theories mentioned above are then defined in detail (principal-agent theory and rent-seeking theory), including their weak points. The article also shows that by combining the theories mentioned above, their weak points can be partly removed. Then the nature of redistribution and parallel game theories are explained. Selected practical examples are then analyzed. The conclusion summarizes the main findings of the paper.

\section{Theory of corruption: Description and Difficulties}

Corruption is a term which denotes a specific contract between at least two people - the corrupter and the person being bribed. Through such a contract the corruptor promises that he/she will provide a service (which can be of a monetary or non-monetary nature) to the bribed person, under the condition that this person gives a particular advantage to the corruptor (such an advantage can be of a tangible or non-tangible nature).

Within such a context, corruption is a result of human action (Ackerman 1999, Otáhal 2006, Otáhal 2007a, Lambsdorff 2007). The parties of corruption act in this manner because corruption brings them some benefits. From the point of human action, the aim of which is to increase some benefits, corruption does not constitute a problem - it is a mutually advantageous exchange (Kohn 2004). The reason we condemn corruption is 
different: there is a third party (neither the corruptor, nor the bribed person) which is harmed by the corruption as it is not in the interest of this third party. For example, company A can be the third party - it did not obtain any order because it was given to company B - the corruptor. If there was no corruption, the order would be given to company A. In this case, due to the corruption, the income and benefits of company A (the third party) were reduced.

Let us assume that the offer (response to the public tender) of company A is more advantageous than the offer of company B. Thus, there are more people affected by corruption. In the case of a public tender, where a public clerk was bribed, all citizens are harmed because if there was no corruption, the difference in the price (or quality) which is offered by company B (a corruptor) and that offered by company A (the third party) could be used for the benefit of citizens. If a manager of a private company is bribed (so the tender is not of public nature), then all owners of the company are in harm - corruption reduces their income.

We believe that our definition is consistent with the frequently mentioned definition of corruption (Nye 1967, 418): "behaviour which deviates from the normal duties of a public role because of privately-biased (family, close private clique), pecuniary or status gains; or violates rules against the exercise of certain types of privately-biased influence. This includes such behaviour as bribery (use of reward to pervert the judgment of a person in a position of trust); nepotism (bestowal of patronage by reason of ascriptive relationship rather than merit); and misappropriation (illegal appropriation of public resources for privately-biased uses)". However, in contrast to this definition, we believe that corruption does not occur only in the public sector. We think that corruption may occur anywhere ${ }^{5}$, too, where the corruptor and the bribed party breach duties set by some norms (from the economic point of -view - by an institution), regardless of whether it is a legal norm (an official institution) or a non-legal norm (unofficial institution). Rules set within a company represent an example of an unofficial institution.

As corruption reduces the income or benefit of a third party - it puts it into disadvantage and, on the contrary, it puts parties of a corruption contract into advantage - it is condemned and penalized. The stated attitude towards corruption can be described on the basis of the principal-agent theory mentioned above. According to this theory, one party of a contract (the principal) hires the other party (the agent) to perform some tasks according to some pre-defined rules. However, interests of the agent may contradict the interests of the principal, and the agent may not fulfil the tasks set by the principal. The agent is considered not to have carried out the tasks, if he/she breached the rules set by the principal (Jensen and Meckling 1974, Perloff 2008). The failure to carry out the principal's tasks set by the agent does not in itself mean corruption - such an action becomes corruption only when the agent does not accomplish the tasks because he/she accepted a bribe from someone else than the principal.

In general, it is possible to state that through corruption an agent accepting a bribe and acting against the tasks which were given to him/her by a principal, violates ownership rights of the principal. For example, if a manager of a private company puts a certain company in advantage based on corruption, he/she violates ownership rights of the

${ }^{5}$ For details see Wallis (2004), Otáhal (2009a), Otáhal (2010). 
company. If corruption is performed by a clerk, he/she violates rights of all citizens. We can therefore agree with the opinion of Benson and Baden (1985) who consider corruption to be an illegal market with ownership rights because corruption violates rules set by the principal in a hidden way, so that the violation is not discovered.

The relationship between the principal and the agent can be encumbered by an asymmetry of information. It may be rather difficult for the principal to monitor whether or not the agent follows his/her instructions (Perloff 2008). In such a case the agent can be tempted to violate the principal's instructions. However, the principal has some instruments which may eliminate agent's temptation to violate instructions. The principal may develop a system of incentives which motivate the agent to act in accordance with his/her desires. Such incentives can be divided into two categories rewards (the agent is rewarded if he/she acts in accordance with instructions of the principal) and punishments (the agent is punished when he/she acts against principal's instructions). However, the reward and punishment cannot be separated from each other. If principals want their agents to behave in a required way, they cannot use only one or the other. We can see a certain analogy with entrepreneurs - when doing business, they have to take into account that if they make a wrong decision, they fail. The threat of failure forces entrepreneurs to seek for right decisions. Similarly, agents must take into account the fact that if they breach instructions given by the principal, they will be punished. The threat of punishment forces agents not to deal in contradiction to instructions of the principal. On the other hand, the threat of failure itself does not sufficiently stimulate an entrepreneur to look for profit opportunities (that means to take right decisions). It is the profit - the reward which he/she wants to attain, what is the stimulus. Similarly, the agent must be rewarded (must obtain something which he/she would not obtain otherwise), when he/she follows the instructions of the principal.

Let us now limit the cases, when the agent acts contrary to instructions of the principal, to only those regarded as corruption. Agents and principals may be members of both the private and the public sector. As stated above, corruption is often (Spector 2005) restricted to corruption of agents who operate in the public sector. It is usually easy to define the agent - in most cases it is a member of a public sector institution (e.g. a clerk of a ministry, of a regional or municipal authority, an MP, etc.). It is somewhat more difficult to define the principal. It could be an organization with which the principal has any kind of relationship (membership, service contract, employment contract, etc.). However, such an organization can be established for a certain purpose in order to satisfy public or social needs. In other words, such an organization can be regarded as an agent of a principal. In this case, the principals would be citizens of a particular territory who established it. In the case of state organizations, it is citizens of the whole territory who are principals (parliament, ministries are regarded as agents of citizens). In the case of regional organizations, only citizens who live or have a long-term residency in the given territory are principals (local councils and municipal authorities can be regarded as agents). We can also find multinational agents - e.g. EU bodies can be considered as agents of all citizens of membership countries. Even though the opinion that a certain public (or international) organization is an agent of a particular group of citizens is unusual (Lambsdorff 2007), we consider it to be substantial, as it is an environment which defines how serious corruption is. In other words, agents of various 
environments violate various ownership rights, while individual violations have a different significance. In our opinion, the breach of duty of a policeman who accepts bribes, for example, is more serious than the breach of duty of a waiter who better serves those guests who give him a tip, even though, according to his/her principal's instructions (an owner of a restaurant), the waiter is supposed to behave similarly to all of his/her guests.

Why do we stress the above-mentioned? We think that the principal-agent theory by itself is unable to define an environment (organizations) in which corruption occurs. If it is unable to define it, then it is unable to define the significance of agents for the survival and development of organizations, and thus it is unable to define the correct system of rewards and punishments which would prevent us from corruption.

The rent-seeking theory regards rent-seeking as behaviour which, in a certain institution (an environment with official and unofficial rules), supports individuals to maximize their benefit in such activities which are non-effective for the institution - they result in a loss for the institution. According to the dynamic version of this theory, it is artificial barriers to entry which stimulate such behaviour (Buchanan 1979, Otáhal 2008a, Otáhal 2008b). According to the rent-seeking theory, corruption occurs in such cases where artificial barriers to entry are created by the means of bribes or other undesirable behaviour (lobbying, etc.). Such barriers are created through a political process in which a group of entrepreneurs tries to make the state (or its part) create such barriers (Tollison 1982, Tullock 1996, Otáhal 2008a). It should be pointed out that corruption does not occur in cases when an entrepreneurial subject provides a bribe so that artificial barriers to entry are removed or at least lowered.

Therefore, the rent-seeking theory does not regard corruption as a voluntary exchange of two parties, in the consequence of which ownership rights of third parties are violated and their benefit lowered. The rent-seeking theory observes consequences of certain behaviour - corruption occurs when certain behaviour creates artificial barriers to entry, which lowers a benefit of the society. As a solution, the rent-seeking theory suggests to reduce artificial barriers, or more precisely, to reduce the possibilities of the state to create them (Otáhal 2008a). Such a recommendation has a problem, as some barriers to entry may be socially effective and may increase a benefit to the society. As an example we can state the barriers to entry into the financial sector; these barriers may, at least partially, prevent persons, who have clearly fraudulent intentions (to make gains through this action), from establishing financial institutions. Generally speaking, the definition of social efficiency is the weak point of the rent-seeking theory. As Rizzo (1979) points out, the definition of social effectiveness is problematic because the effectiveness can be defined only in relation to the goals which are to be achieved by an acting person. However, individuals have various goals, and thus it is not possible to state if certain behaviour is effective from the social point of view.

\section{Theory of redistribution systems and corruption}

The preceding text indicates that the two major economic theories that deal with the problem of corruption face certain difficulties. The principal-agent theory has difficulties with defining an environment in which agents offering and accepting corruption operate. Logically, it then encounters problems with defining the significance of agents for the survival and development of organizations in such an environment. 
The rent-seeking theory has a problem with defining effectiveness of artificial barriers to entry. Besides that, it faces a problem with defining the rules which create artificial barriers and those which do not. In general, the rent-seeking theory has a problem with creating means (incentives) leading to a non-corrupted behaviour of individuals. In order to tackle the issue of corruption successfully, the solution of the problems of the theories mentioned above is vital. If the principal-agent theory does not define an environment in which an agent operates and does not determine an agent's significant role for the survival of an organization, then it is unable to determine incentives which prevent the agent from acting in a corrupted way.

If the rent-seeking theory does not determine the barriers to entry that motivate clerks, politicians and entrepreneurs to act in a corrupted way, then it is unable to set correct rules which lead to economic development and which, at the same time, prevent agents from acting in a corrupted way. In this section we investigate if both problems can be solved by the means of the theory of redistribution systems and its part - the theory of parallel redistribution games.

The theory of redistribution systems is based on the fact that most social systems, i.e. an environment in which people exist, have the character of a redistribution system where estates, pensions and resources are being redistributed among individual members of the system. In other words, some members of the system gain estates, pensions or resources without having any right to gain them, as a consequence of their efficiency, and others lose them, despite the fact that they, thanks to their efficiency, have a right to get them. From this point of view, the redistribution system can be defined as a system in which individual members are rewarded differently depending on their efficiency (Valenč́k 2008). We need to point out that redistribution has some objective reasons, especially in those systems where people themselves are unable to ensure sufficient resources, estates or pensions for their life. This concerns children, elderly and sick people or invalids, etc. If the society wants to ensure the life of such people, it must necessarily redistribute the benefits. The history shows that the given redistribution has been occurring since the beginning of human existence. After all, the human kind would not otherwise survive. From the philosophical point of view, the given redistribution is a manifestation of humanity, of meeting in the I-You mode, it is a type of behaviour through which people socialize - through redistribution they learn how to collaborate, cooperate, how to help and be solidary. People encounter redistribution from their birth. They take it for granted. From this standpoint, the redistribution system is immanent for an individual. Philosophically speaking, a man is born and thrown into the redistribution system. Therefore, Potůček (2005) rightly notes that all economic and social systems are redistribution systems at the same time. The redistribution in favour of people who need it can be called necessary (desired) (Wawrosz 2011).

The desired distribution is necessary to be separated from another type of distribution where a person, for whose benefit we redistribute, is able to ensure resources and estates for his/her living him/herself. In other words, we do not redistribute for this person. In the case of undesired redistribution, income and property differences, which may put the system stability and development in danger, are not levelled but, on the contrary: people for whose benefit we redistribute gain unjustified advantage. One of the reasons why the undesired redistribution occurs is that people are used to some sort of redistribution; 
have been since their birth. If some redistribution takes place in the long term (this is a manifestation of the existing system of official and unofficial institutions), it may result in redistribution being taken for granted, not-in-doubt, and people do not take into account (or not enough) that the redistribution system might change. Receivers of redistribution benefits (though the redistribution is undesired) may argue that such redistribution has always been traditional, and when others try hard to make the society redistribute for their benefit (which is not usual), they may point out that there are other, already existing ways of redistribution, or show analogies of already existing forms of redistribution with a newly proposed form, etc.

It is obvious that the criterion whether some redistribution is or is not needed is always arbitrary and it is a matter of opinion. In practice, it involves discussions about social security benefits and their amount, about which groups should be supported (e.g. all families with children or just families whose income is under a certain level), about from which age can children without means start working, about which state of disability entitles you to gain a full disability pension, etc. Due to the fact that such discussions depend on different opinions on values in general, it is not possible to expect any unambiguous result.

The economic theory must have noticed that redistribution reduces efficiency of a system (regarding the volume of estates which can be produced with resources available). It is quite logical: resources used for redistribution cannot be used to produce new goods. Furthermore, redistribution puts off people who gain and those who lose. Those who gain by the means of redistribution may not be stimulated to gain resources, estates or pensions by themselves because they will always get something. Those who lose due to redistribution know that a part of their resources, estates or pension will be taken away from them, and thus they do not need to take efforts to maximize their gains. The economic theory then states - the higher redistribution within the system is, the bigger is the fall of efficiency. The given relationship is often interpreted as a relationship between equality and efficiency. ${ }^{6}$ Let's point out that efficiency falls more in the systems of undesired redistribution (Wawrosz 2011).

The desired and undesired redistribution must be adjusted by certain official and unofficial rules which define for whose benefit and at whose expense it is to be redistributed, how much and in which way, etc. We have to stress that such rules are considered to be standards of society and redistribution takes place in compliance with them. Such redistribution can be then called legal, where the word "legal" means that it is done in compliance with the given standards. It should be stressed that these standards do not have to be of an official (legal) nature, that means they do not have to be in the form of acts, directions, regulations etc., but that they can have the form of unofficial rules (e.g. moral rules, customs, traditions, etc.) Thus, in our meaning, the word "legal" does not only concern the recognized state law.

However, besides the legal systems of redistribution, there are other forms of

\footnotetext{
${ }^{6}$ In theory, the dilemma is described by Okun (1975). The dilemma, including the text as shown in this figure which expresses the dependence, is presented for instance in Musgrave (2004), Stiglitz (2000). Empirical studies can then mention a study by Kuhn and Riddell (2006), which for example on different unemployment insurance systems in Canada shows that systems with higher unemployment benefits lead to more unemployment and prolonged unemployment.
} 
redistribution: parallel redistribution systems. The basic characteristics of a parallel system of redistribution is as follows:

- In a parallel redistribution system, rules that exist within the original redistribution system are violated through acts which are not allowed in the system of original redistribution.

- Redistribution that occurs in a parallel redistribution system is hidden and secret.

- Redistribution in favour of members of a parallel system of redistribution is happening at the expense of the original redistribution system within which the parallel system of redistribution exists.

The fact that each system of parallel redistribution game corresponds with a specific type of disruption of the institutional system is a typical feature of the parallel redistribution system - A parallel redistribution system (game) disrupts the legal institutional arrangement of a redistribution system, while such disruption is hidden, i.e. those, who disrupt, try to stay undiscovered by other subjects (players) who might find out and intervene against them. From the point of the new institutional economy (Furubotn and Richter 2005, Otáhal 2009b), parallel redistribution games can be described as a manifestation of an opportunistic behaviour game - individual subjects behave in a different way than is set by respective institutions. Thus, corruption can be considered as an example of a parallel redistribution game - in contradiction to the rules, the aim of corruption is to redistribute resources which should be available for a third party, too (not participating in the redistribution contract), for the benefit of the corruption contract participants.

\section{Multidimensional analysis of corruption}

The general theory of redistribution systems can describe a complex corruption environment. At the same time, it can also identify barriers to entry which bring economic agents to corruption and which reduce efficiency of the whole system. Generally speaking, a barrier to entry is classified as an undesired form of redistribution, where certain subjects gain some advantage, and thus a higher income (or more estates or resources), while there is no reason why other subjects should not (also) have the given advantage. Barriers to entry can be then classified according to how they reduce the efficiency of the given system. According to the theory of redistribution systems, corruption itself is defined as a form of a parallel redistribution game within which a legal (official or unofficial) institutional system is disrupted.

In this section, we explain some empirical observations from the perspective of the theory of redistribution systems. We provide cluster analysis of the member states of the European Union. The cluster analysis includes all its members, except for Malta and Cyprus. These two countries were excluded from the analysis because data for some indicators related to them were not available. Indicators used in this cluster analysis are as follows: Corruption Perceptions Index, Index of Economic Freedom and World Governance Indicators (Voice and Accountability, Political Stability and Absence of Violence/Terrorism, Government Effectiveness, Regulatory Quality, Rule of Law, Control of Corruption) - as countries' measurements of quality of institutions (formal 
and informal), and GDP per Capita in PPS, Unemployment Rate, Labour Productivity per Person Employed, Net Earnings in PPS - as countries' measurements of performance.

The cluster analysis is a multidimensional method that allows division of the units based on their multidimensional similarity into homogeneous subgroups, so that similar statistical units are categorized into the same group (by specific values of the particular multidimensional property), while statistical units in different subgroups will be as diverse as possible (by the values of the same multidimensional property). This analysis has many advantages. Such methods do not require pre-calculation adjustments of the data and they allow us to uncover extreme deviations in the registered values of the multidimensional property. At the same time, these values will form a separate cluster after the calculation. The application of the cluster analysis and other quantitative methods were explored, for example, by Jajuga et al. (2002). There is a wide choice of clustering methods available. We use the methodology of hierarchical clustering, specifically the method of the furthest neighbour with Euclidean measure of distance, which determines the distance between clusters by the distances between two furthest units from different clusters described in Palát (2009). Results of the hierarchical clustering process can then be transparently represented by dendrograms that serve as the graphical illustration of results.

Figures 1-3 present dendrograms based on cluster analysis in 2000, 2005 and 2010. Our interpretation of presented dendograms follows implications of the theory of redistribution systems and its part theory of parallel games. Theory of redistribution systems understands each country as an independent redistribution system. Institutional quality measurements (Index of Economic Freedom and World Governance Indicators like Voice and Accountability, Political Stability and Absence of Violence/Terrorism, Government Effectiveness, Regulatory Quality and Rule of Law) approximate the quality of countries' redistribution mechanisms of formal and informal institutions. Performance measurements (GDP per Capita in PPS, Unemployment Rate, Labour Productivity per Person Employed, Net Earnings in PPS) indicate performance of countries' redistribution systems. Furthermore, corruption perceptions measurements (Corruption Perceptions Index, Control of Corruption) might be interpreted as indicators of the level of parallel redistribution games allowed by formal redistribution mechanisms (i.e. Voice and Accountability, Political Stability, Government Effectiveness and Rule of Law) (Grochová and Otáhal 2010, Grochová and Otáhal 2011).

The cluster analysis testable hypothesis implied by the theory of redistribution systems and its part theory of parallel games connects countries with similar qualities of redistribution mechanisms of formal and informal institutions and similar performance. Typical examples are Romania, Slovakia, and Bulgaria or Luxembourg, United Kingdom, and Ireland in 2000 (Figure 1). In 2005, Belgium, Austria, and Spain (Figure 2) might be good examples, whilst Denmark, and Germany, or Estonia, Poland, and Hungary might be typical examples of 2010 (Figure 3). 
Figure 1: Dendrogram from Corruption Perceptions Index, Index of Economic Freedom and World Governance Indicators (Voice and Accountability, Political Stability and Absence of Violence/Terrorism, Government Effectiveness, Regulatory Quality, Rule of Law, Control of Corruption), GDP per Capita in PPS, Unemployment Rate, Labour Productivity per Person Employed, Net Earnings in PPS in the countries of the European Union in 2000.

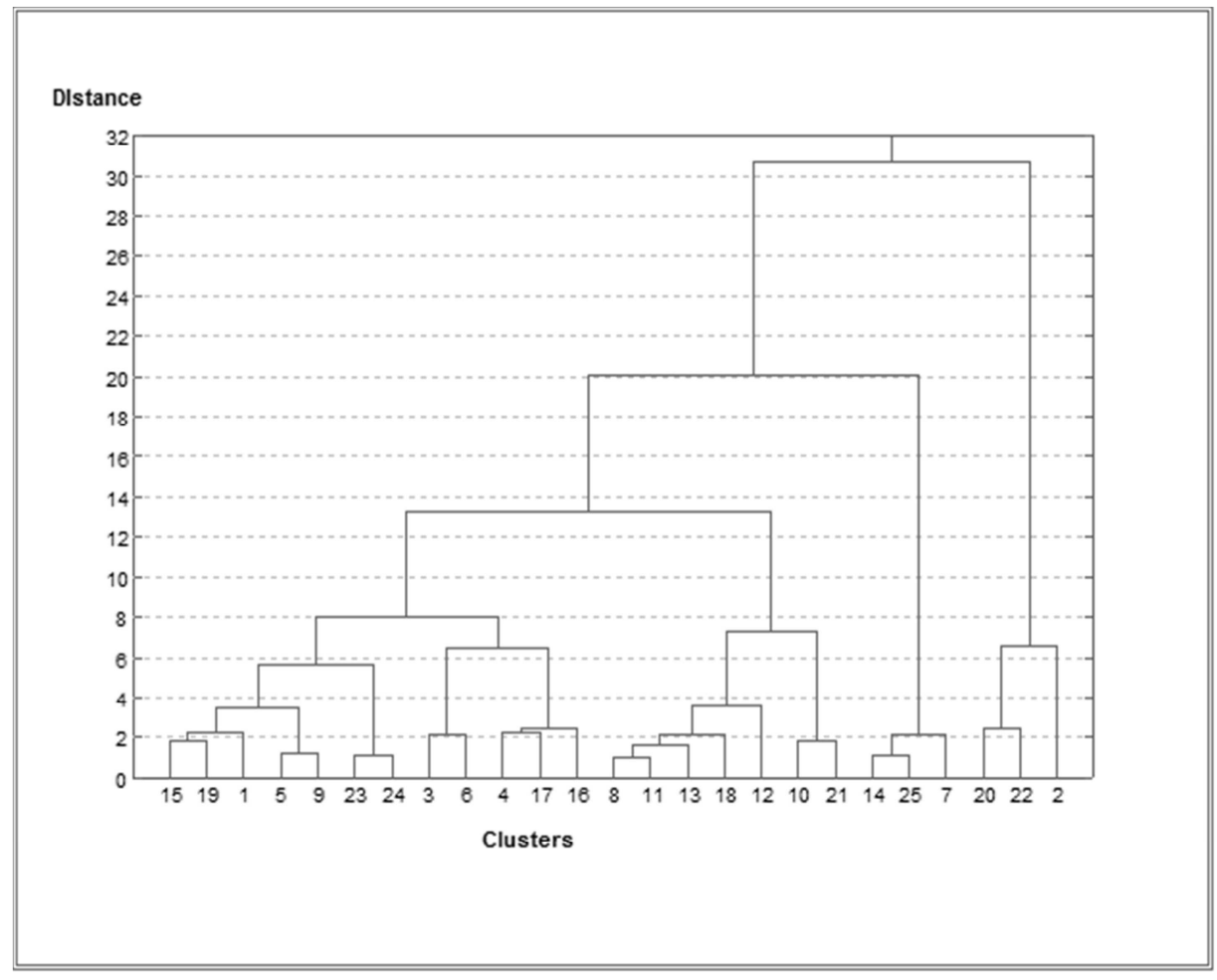

Note: 1 - Belgium, 2 - Bulgaria, 3 - Czech Republic, 4 - Denmark, 5 - Germany, 6 - Estonia, 7 Ireland, 8 - Greece, 9 - Spain, 10 - France, 11 - Italy, 12 - Latvia, 13 - Lithuania, 14 Luxembourg, 15 - Hungary, 16 - Netherlands, 17 - Austria, 18 - Poland, 19 - Portugal, 20 Romania, 21 - Slovenia, 22 - Slovakia, 23 - Finland, 24 - Sweden, 25 - United Kingdom.

Source: Our calculations, data available from: Corruption Perception Index: http://www.transparency.org/policy_research/surveys_ indices/cpi, World Wide Governance Indicators: http://info.worldbank.org/governance/wgi/sc_ country.asp, Index of Economic Freedom: The Heritage Foundation: http://www.heritage.org/index/ Default.aspx, GDP per Capita in PPS, Unemployment Rate, Labour Productivity per Person Employed, Net Earnings in PPS: http://epp.eurostat.ec.europa.eu/portal/page/portal/statistics/search_database. 
Figure 2: Dendrogram from Corruption Perceptions Index, Index of Economic Freedom and World Governance Indicators (Voice and Accountability, Political Stability and Absence of Violence/Terrorism, Government Effectiveness, Regulatory Quality, Rule of Law, Control of Corruption), GDP per Capita in PPS, Unemployment Rate, Labour Productivity per Person Employed, Net Earnings in PPS in the countries of the European Union in 2005.

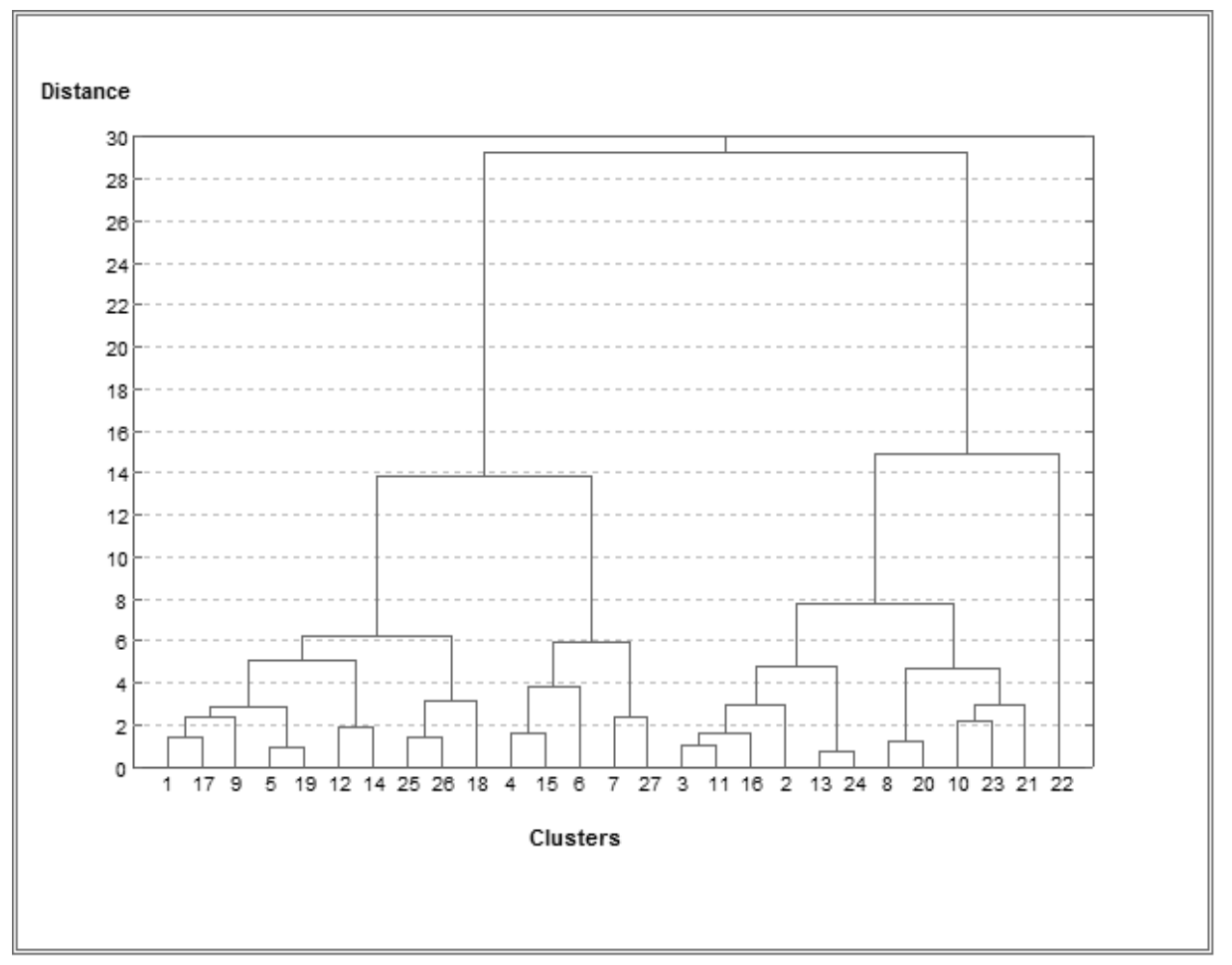

Note: 1 - Belgium, 2 - Bulgaria, 3 - Czech Republic, 4 - Denmark, 5 - Germany, 6 - Estonia, 7 Ireland, 8 - Greece, 9 - Spain, 10 - France, 11 - Italy, 12 - Latvia, 13 - Lithuania, 14 Luxembourg, 15 - Hungary, 16 - Netherlands, 17 - Austria, 18 - Poland, 19 - Portugal, 20 Romania, 21 - Slovenia, 22 - Slovakia, 23 - Finland, 24 - Sweden, 25 - United Kingdom.

Source: Our calculations, data available from: Corruption Perception Index: http://www.transparency.org/policy_research/surveys_ indices/cpi, World Wide Governance Indicators: http://info.worldbank.org/governance/wgi/sc_ country.asp, Index of Economic Freedom: The Heritage Foundation: http://www.heritage.org/index/ Default.aspx, GDP per Capita in PPS, Unemployment Rate, Labour Productivity per Person Employed, Net Earnings in PPS: http://epp.eurostat.ec.europa.eu/portal/page/portal/statistics/search_database. 
Figure 3: Dendrogram from Corruption Perceptions Index, Index of Economic Freedom and World Governance Indicators (Voice and Accountability, Political Stability and Absence of Violence/Terrorism, Government Effectiveness, Regulatory Quality, Rule of Law, Control of Corruption), GDP per Capita in PPS, Unemployment Rate, Labour Productivity per Person Employed, Net Earnings in PPS in the countries of the European Union in 2010.

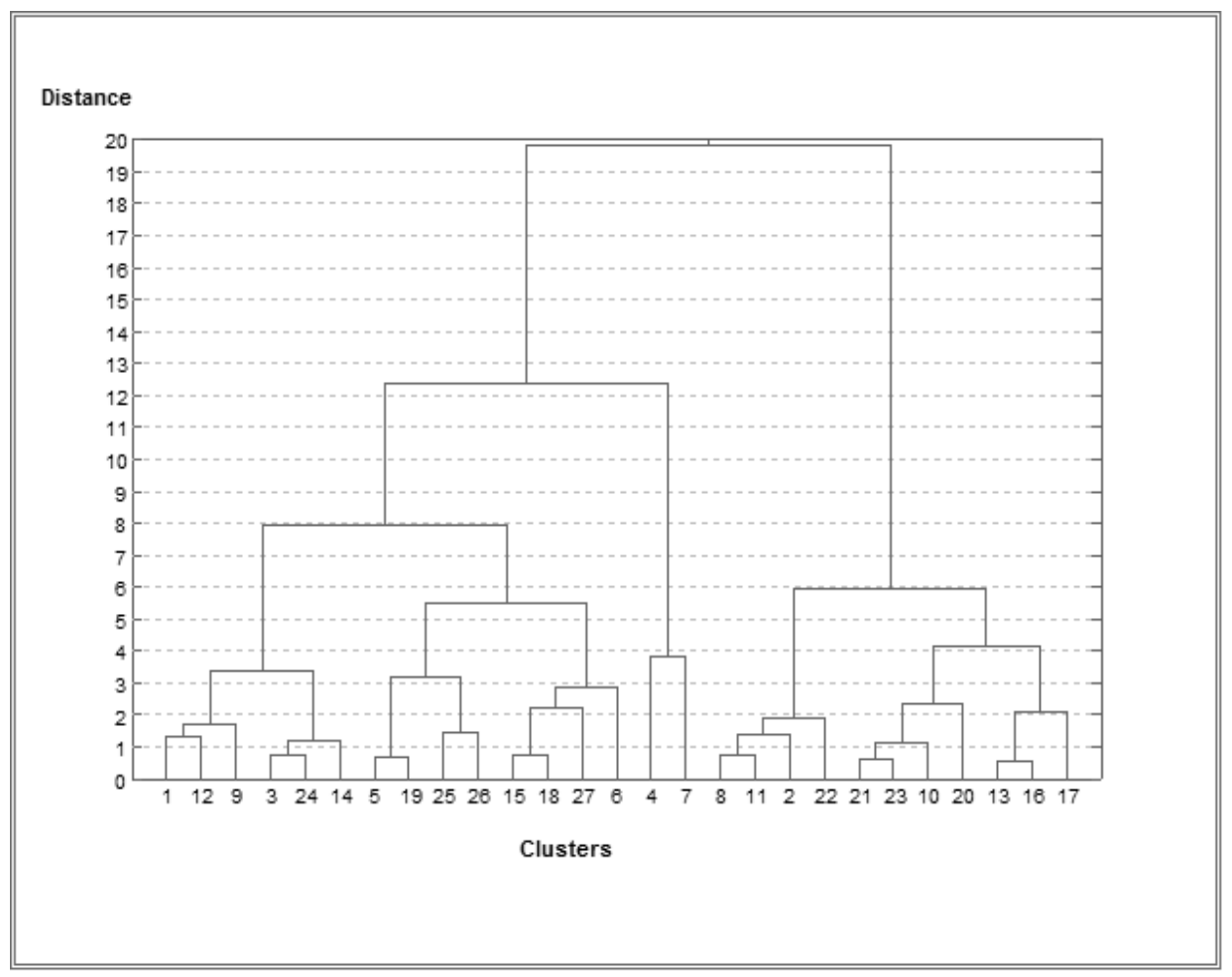

Note: 1 - Belgium, 2 - Bulgaria, 3 - Czech Republic, 4 - Denmark, 5 - Germany, 6 - Estonia, 7 Ireland, 8 - Greece, 9 - Spain, 10 - France, 11 - Italy, 12 - Latvia, 13 - Lithuania, 14 Luxembourg, 15 - Hungary, 16 - Netherlands, 17 - Austria, 18 - Poland, 19 - Portugal, 20 Romania, 21 - Slovenia, 22 - Slovakia, 23 - Finland, 24 - Sweden, 25 - United Kingdom.

Source: Our calculations, data available from: Corruption Perception Index: http://www.transparency.org/policy_research/surveys_ indices/cpi, World Wide Governance Indicators: http://info.worldbank.org/governance/wgi/sc_ country.asp, Index of Economic Freedom: The Heritage Foundation: http://www.heritage.org/index/ Default.aspx, GDP per Capita in PPS, Unemployment Rate, Labour Productivity per Person Employed, Net Earnings in PPS: http://epp.eurostat.ec.europa.eu/portal/page/portal/statistics/search_database. 
It can be objected that clusters bring together countries with different value ${ }^{7}$ of CPI. For instance in Figure 3 (data for 2010) one of the clusters puts together Belgium (value of CPI 7.1), Spain (CPI = 6.1) and Latvia (CPI = 4.3). It is necessary to emphasize that CPI is one of many indicators (see above) for cluster analysis. The method of clustering (Palát 2009) used is based on aggregate performance, not on similarity in one indicator. The value of CPI can be biased. As for instance Wilhelm (2002) notes, CPI figures are acknowledged as somewhat subjective because an objective approach is almost impossible. Respondents in some countries can over or under value the real level of corruption. For instance, they can understand some behaviour as non-corrupted although in other countries, it is considered as corrupted. As the result the level of CPI is overvalued. Oppositely: an efficient and incorruptible judicatory (including the police and public prosecutor's office) may result in high conviction rate. Instead of acknowledging this, "objective data" would punish country with bad score. So CPI should not be considered to be the only indicator of corruption, and other measurement of corruption should be made. Our cluster analysis works with more indicators that allow more precious results.

\section{Conclusion}

In this paper, we argued that existing economic theories dealing with the issue of corruption, i.e., principal-agent theory and rent-seeking theory, suffer from serious problems, so in the fight against corruption they can lead to both incorrect methods of fighting and conclusions. The principal-agent theory has a problem to define an environment in which agents performing corruption act. Besides that, it also has a problem to explain the significance of agents in the survival of their environment. On the other hand, the rent-seeking theory finds it difficult to determine the efficiency of artificial barriers to entry.

Due to the deficiencies of the given theories, we described the theory of redistribution systems and parallel redistribution games because we think that they solve the issue of corruption more efficiently. We found out that the theory of redistribution systems a) defines an environment in which corruption occurs as a legal system of redistribution; b) defines a parallel redistribution system (the game) as a system in which violations of legal rules of the redistribution system occur, and it defines corruption as an example of a parallel redistribution; c) based on the definitions contained in the points a) and b) concludes that by reducing the legal redistribution (especially undesired redistribution) opportunities of agents to perform corruption are eliminated; and finally d) is able to describe what the rules which discourage agents from corruption should look like.

Further research should consist of detailed characteristics of redistribution systems, parallel redistribution games and mainly strategies applied in legal and parallel redistribution systems. It is desirable to describe individual agents, to characterize them, to describe how they contribute to the survival and development of an organization. An analysis of past cases and situations might also be a suitable way of such description.

\footnotetext{
${ }^{7}$ The CPI scale has 10 points (from 0 to 10 ). The higher the value, the lower level of corruption.
} 


\section{References}

ACKERMAN, S. R. (1999). Corruption and Government: Causes, Consequences, and Reform. Cambridge UK: Cambridge University Press.

BARDHAN, P. (1997). Corruption and Development: a review of issues. Journal of Economic Literature. 35(3), pp. 1320-1346.

BENSON, B. L., BADEN, J. (1985). The Political Economy of Governmental Corruption: The Logic of Underground Government. Journal of Legal Studies. 14(2), pp. 391-410.

BUCHANAN, J. M. (1979). Is Economics the Science of Choice? In What Should Economist Do? Indianapolis (IN): Liberty Fund.

COLOMBATTO, E. (2003). Why is corruption tolerated? Review of Austrian Economics. 16(4), pp. 367-379.

FURUBOTN, E. G., RICHTER, R. (2005). Institutions and Economic Theory. 2nd Edition. Michigan: The University of Michigan Press.

GROCHOVÁ, L., OTÁHAL, T. (2011). Corruption in the Czech and the Slovak Republics: Did the EU Pressure Improve Legal Framework and Its Enforcement? Acta Universitatis Agriculturae et Silviculturae Mendelianae Brunensi. 14(7), pp. 1-15.

GROCHOVÁ, L., OTÁHAL, T. (2010). Podnikání a ekonomický rozvoj: jaký je rozdíl mezi neo-Rakouskou a novou institucionální ekonomií? Politická ekonomie. 58(5), pp. 623-640.

JAJUGA, K. et al. (2002). Classification, Clustering and Data Analysis: Recent Advances and Application. Berlin: Springer.

JENSEN, M. C., MECKLING, W. H. (1974). Theory of the Firm: Managerial Behavior, Agency Cost and Ownership Structure. Journal of Financial Economics. 4(2), pp. 305360 .

KOHN, M. (2004). Value and Exchange. CATO Journal. 24(3), pp. 303-339.

KUHN, P., RIDDELL, CH. (2010). The Long-Term Effects of a Generous Income Support Program: Unemployment Insurance in New Brunswick and Maine, 1940-1991. Industrial and Labor Relations Review. 63(2), pp. 183-204.

LAMBSDORF, J. G. (2002). Corruption and rent-seeking. Public Choice. 113(1-2), pp. 97-125.

LAMBSDORFF, J. G. (2007). The institutional economics of corruption and reform: theory, evidence, and policy. Cambridge: Cambridge University Press.

MIESES, L. (1949). Human action: a treatise on economics. New Haven: Yale University Press.

MUSGRAVE, R. (2004). Public Finance in Theory and Practice. Noida: Tata McGraw-Hill Education.

NYE, J.S. (1967). Corruption and Political Development: A Cost-Benefit Analysis. 
American Political Science Review. 61(2), pp. 417-427.

OKUN, A. M. (1975). Equality and Efficiency - The Big Tradeoff. Brookings Institution Press.

OTÁHAL, T. (2006). Ekonomická analýza definice korupce. Národohospodářrský obzor. 4(1), pp. 50-60.

OTÁHAL, T. (2007a). Corruption: A Theoretical Note. In Proceedings of International Bata Conference for Ph.D. Students and Young Researchers. Zlín: TBU in Zlín.

OTÁHAL, T. (2007b). Why is Corruption a Problem of the State? Prague Economic Papers. 7(2), pp. 165- 179.

OTÁHAL, T. (2008a). Na obranu dobývání renty. Ekonomický časopis. 56(10), pp. 1019-1032.

OTÁHAL, T. (2008b). Teorie podnikatelského objevování. Politická ekonomie. 56(5), pp. 669-683.

OTÁHAL, T. (2009a). Korupce ve spontánním řádu. Scientia et Societas. 5(1), pp. $137-$ 148.

OTÁHAL, T. (2009b). Problém zastoupení v nové institucionální ekonomii. Politická ekonomie. 57(5), pp. 677-695.

OTÁHAL, T. (2010). Srovnání teorií korupce. Scientia et Societas. 6(3), pp. 143-158.

PALÁT, M. (2009). Analýza trhu práce v České republice s důrazem na nezaměstnanost vzhledem $\mathrm{k}$ dalším zemím Evropské unie. Acta Universitatis Agriculturae et Silviculturae Mendelianae Brunensis. 57(6), pp. 189-200.

PERLOFF, J. M. (2008). Microeconomics: theory \& applications with calculus. London: Pearson/Addison-Wesley.

POTU゚ČEK, M. (1997). Nejen trh. Praha: Sociologické nakladatelství.

RIZZO, M. J. (1979) Uncertainty, Subjectivity, and the Economic Analysis of Law. In RIZZO, M (Eds.), Time, Uncertainty, and Disequilibrium: Exploration of Austrian Themes. Massachusetts Toronto: Lexington Books D.C.

SPECTOR, B. I. (2005). Fighting Corruption in Developing Countries: Strategies and Analysis. Sterling: Kumarian Press.

STIGLITZ, J. E. (2000). Economics of the Public Sector. New York USA: W. W. Norton \& Company.

TOLLISON, R. D. (1982). Rent Seeking: A Survey. Kyklos. 35(4), pp. 576-602.

TREISMAN, D. (2000). The causes of corruption: A cross-national study. Journal of Public Economics. 76(3), pp. 399-457.

TULlOCK, G. (1996). Corruption Theory and Practice. Contemporary Economic Policy. 14(3), pp. 6- 13.

VALENČÍK, R. (2008). Teorie her a redistribuční systémy. Praha: VŠFS - Eupress. 
VALENČÍK, R., BUDINSKÝ, P. (2009). Teorie redistribučních systémů. Politická ekonomie. 57(5), pp. 644-659.

WILHELM, P. G. (2002). International validation of the corruption perceptions index: Implications for business ethics and entrepreneurship education. Journal of Business Ethics. 35(3), pp. 177-189.

WALLIS, J.J. (2004). The Concept of Systematic Corruption in American Political and Economic History. NBER Working Paper 10952.

WAWROSZ, P. (2011). Dosahování a narušování institucionální rovnováhy v redistribučních systémech. Politická ekonomie. 59(4), pp. 526-546. 